Journal of Advanced Research in Fluid Mechanics and Thermal Sciences

\title{
Development of An Air-Stage Downdraft Gasifier and Performance Evaluation on Feedstock of Rice Husk
}

\author{
Anak Agung Putu Susastriawan ${ }^{1, *}$, Yuli Purwanto ${ }^{1}$, Purnomo $^{1}$, Ahmad Warisman ${ }^{1}$ \\ 1 Department of Mechanical Engineering, Faculty of Industrial Technology, Institut Sains dan Teknologi AKPRIND, Yogyakarta, Indonesia
}

\begin{tabular}{|c|c|}
\hline ARTICLE INFO & ABSTRACT \\
\hline $\begin{array}{l}\text { Article history: } \\
\text { Received } 25 \text { March } 2021 \\
\text { Received in revised form } 17 \text { May } 2021 \\
\text { Accepted } 25 \text { May } 2021 \\
\text { Available online } 24 \text { June } 2021\end{array}$ & $\begin{array}{l}\text { Due to depletion of conventional fuel and increasing global warming, biomass wastes } \\
\text { have been explored and investigated by many researchers worldwide. A biomass } \\
\text { gasification power plant is a promising conversion technology for energy sustainability } \\
\text { From many existing gasifiers have been developed, mostly they have high technology, } \\
\text { large capacity, and very costly, thus unsuitable for remote area di Indonesia. The } \\
\text { present work aims to build a simple and low cost double air-stage downdraft gasifier } \\
\text { for a small-scale biomass power plant system. The gasifier is tested on rice husk at } \\
\text { equivalence ratio of } 0.20,0.30 \text {, and } 0.40 \text {. The parameters evaluated are axial } \\
\text { temperature, fuel consumption rate, heating rate, thermal efficiency, and tar content } \\
\text { The results show that the highest gasification temperature, fuel consumption rate, } \\
\text { heating rate, and thermal efficiency are occurs at equivalence ratio of } 0.4 \text {. The values } \\
\text { are } 904.5^{\circ} \mathrm{C}, 4.14 \mathrm{~kg} / \mathrm{h}, 25.38 \mathrm{~kJ} / \mathrm{h} \text {, and } 63.18 \% \text {, respectively. The significant findings is } \\
\text { that the gasifier generates producer gas with low tar content, i.e. } 23.9 \mathrm{mg} / \mathrm{m}^{3} \text { at } \\
\text { equivalence ratio of } 0.4 \text { and the producer gas is successfully used to run the } 3 \mathrm{~kW} \\
\text { generator set. For sustainability operation of the power plant, it is important to test } \\
\text { the gasifier on various biomass waste feedstocks. }\end{array}$ \\
\hline
\end{tabular}

\section{Introduction}

Shortage of petroleum fuel and increasing global warming have been concerned worldwide, including Indonesia. The renewable energy sources are promising replacement for petroleum based energy [1]. The search of renewable energy sources increases significantly in a last decade. Many renewable sources of energy, such as various biomass wastes have been explored and investigated by many researchers around the globe. Typically, biomass contains carbon $(C)$, hydrogen $(H)$, oxygen $(\mathrm{O})$, nitrogen $(\mathrm{N})$ and some minerals. Biomass energy has low dependence climate and site which give an advantage over other renewable energy [2]. The use of energy from biomass is a safe way that able to reduce dependence on fossil fuels, minimize emission to atmosphere, enhance biomass energy utilization, and attain zero carbon foot print [3]. Biomass wastes can be turned to useful fuel by means thermochemical processes. Gasification is a one of many thermochemical biomass

\footnotetext{
* Corresponding author.

E-mail address: agung589E@akprind.ac.id
}

https://doi.org/10.37934/arfmts.84.1.2032 
conversion processes [4]. Indonesia has a biomass energy potential approximately to $33 \mathrm{GW}$ which can be obtained from agricultural, forestry, and crop residues. However, only about $1.6 \mathrm{GW}$ of the total Indonesia biomass potential has been used as useful energy sources [5].

Biomass gasification is very promising technology that can be applied for utilization of biomass wastes. Since a producer gas from biomass gasification can be used directly as a fuel, biomass gasification is accepted as the most attractive method for the enhancement of biomass energy [6]. Compared with direct combustion of the biomass, combustion of producer gas is cleaner [7]. Biomass gasification transforms solid biomass into producer gas in the gasifier involving four thermo-chemical reactions. The reactions are oxidation, reduction, pyrolysis, and drying [8]. Contrast with combustion, gasification needs very less amount of oxidizer. In gasification, atmospheric air, steam, or pure oxygen are commonly used as oxidizer or known as gasification medium in gasification. Producer gas, a product of gasification, can be applied as a fuel of a burner as well as a fuel of an internal combustion engine. According to Basu [8], reactor of gasifier can be grouped into fixed or moving bed gasifier, fluidized bed gasifier, and entrained flow gasifier. Considering relative flow direction between producer gas and feedstock in the reactor, the moving bed reactor is further divided as downdraft reactor, updraft reactor, and cross-draft reactor [8-10]. Meanwhile, fluidized bed reactor classified into bubbling fluidized bed and circulating fluidized bed [10].

Over other gasifiers, a downdraft gasifier is more appropriate for small scale biomass gasification system. The downdraft gasifier has a simple construction and generate a producer gas with low tar content. Many success biomass gasification systems have been reported worldwide. The producer gas has been explored as a fuel of either Spark Ignition (SI) engine [11-13] or Compression Ignition (Cl) engine [14-16]. In downdraft gasifier, the feedstock and the producer gas flow downward in the reactor during gasification. The generated producer gas exits the gasifier thru gas outlet located at a lower part of a reactor. Sequence processes, start from top to the bottom of the downdraft gasifier are drying, pyrolysis, oxidation, and reduction. Reduction process which involves Bouduard (R1), Water-Gas (R2), Water-Gas Shift (R3), and Methane formation (R4) reactions forms combustible gas $\mathrm{CO}, \mathrm{H}_{2}$, and $\mathrm{CH}_{4}$

$$
\begin{aligned}
& \mathrm{C}+\mathrm{CO}_{2} \rightarrow 2 \mathrm{CO}+172 \mathrm{~kJ} / \mathrm{mol} \\
& \mathrm{C}+\mathrm{H}_{2} \mathrm{O} \rightarrow \mathrm{CO}+\mathrm{H}_{2}+131 \mathrm{~kJ} / \mathrm{mol} \\
& \mathrm{CO}+\mathrm{H}_{2} \mathrm{O} \rightarrow \mathrm{CO}_{2}+\mathrm{H}_{2}-41,2 \mathrm{~kJ} / \mathrm{mol} \\
& \mathrm{C}+2 \mathrm{H}_{2} \rightarrow \mathrm{CH}_{4}-74,8 \mathrm{~kJ} / \mathrm{mol}
\end{aligned}
$$

Performance of the gasifier can be influenced by various operating parameters, i.e. equivalence ratio, gasification temperature, and biomass type. Equivalence ratio significantly affects the composition of the producer gas and gasification rate [17]. The equivalence ratio is termed as the ratio between an actual amounts of air used in gasification to stoichiometric air for combustion [18]. Typically for effective gasification, Optimum equivalence ratio for biomass gasification is 0.2-0.4 [19]. Gasification turns to pyrolysis when equivalence ratio below 0.2 and moves to combustion when equivalence ratio above 0.4 [20]. Equivalence ratio is proportional to oxidation rate [21] and biomass consumption rate [22]. Increasing equivalence ratio, mole percentages of hydrogen and carbon monoxide reduce whereas mole percentages of carbon dioxide and nitrogen improve $[23,24]$. By 
increasing equivalence ratio, the syngas mass fraction in the products of rice hulls gasification also escalates, which ranged from $88-89 \%$ [25].

Meanwhile, temperature also gives good effect on combustible gas content of the producer gas by improving formation of hydrogen during reduction process $[6,24,26,27]$. By steeping up gasification temperature, tar content of producer gas and char yields decline [6]. At high gasification temperature, tar cracking process takes place well and energy content of the producer gas improves [28]. Maximum heating value of $4.5 \mathrm{MJ} / \mathrm{Nm}^{3}$ of wood gas was obtained at optimum oxidation temperature of $955^{\circ} \mathrm{C}$ [29]. Gasification temperature is influenced by equivalence ratio. Gasification temperature enhances as equivalence ratio increases [21]. Oxygen availability increases as equivalence ratio steps up, results in enhancing oxidation process so that releases more heat.

Besides equivalence ratio and temperature, biomass type also has significant effect on performance of the gasifier. For similar equivalence ratio, producer gas composition between mesquite wood and juniper wood were different [23]. Cold gas efficiency (CGE) and carbon conversion efficiency (CCE) were also different between gasification of carbonized pellet and gasification of carbonized wood briquettes at equivalence ratio of 0.24 [30]. Meanwhile, Kardas et al., [31] found that the net calorific value of syngas from beech wood was higher than that of syngas from refuse derived fuel (RDF). Biomass with more lignin content produced more hydrogen than others. Gasification rates of cellulose and hemicellulose are higher than gasification rate of lignin. Cellulose and hemicellulose generate more carbon monoxide and methane but less hydrogen and carbon dioxide. Whereas, the real biomass fell in between [32].

In developing gasifier-IC engine system for power plant, it is required tar removal of the producer gas. Tar is a mixture of condensable hydrocarbons, with compound of aromatic [33-35]. Due to corrosive property of the tar, it is disallowed direct utilization of a producer gas [36]. In power application, tar in producer gas may block and contaminate the fuel line, filter, engine, and turbine [37]. The deposit of the burnt tar in the cylinder head may increase the tendency of the engine experiences over heat which can cause severe damage of the engine. The simple method to figure out the engine from over heat is that by recording cylinder and exhaust gas temperature when the engine is operated on the producer gas. Milne et al., [38] recommended that producer gas contains tar less than $100 \mathrm{mg} / \mathrm{Nm}^{3}$ when the gas is used for internal combustion engine. Wet scrubber is an important unit in gasifier system to reduce tar content in a producer gas. The scrubber has a function as cooling and scrubbing device Performance of the scrubber is affected by several factors such as thermal conductivity of the scrubbing fluid. In order to increase thermal conductivity of the scrubbing fluid, hybrid PCM (phase change materials) with graphene filler could be used to achieve higher thermal conductivity [39].

From many existing gasifiers have been developed, mostly they have high technology, huge capacity, and very costly, thus unsuitable for remote area di Indonesia The present work aims to design and fabricate a simple and low cost an air-stage downdraft gasifier and evaluate its performance. The performance of the gasifier is evaluated by running the gasifier on a feedstock of rice husk at different equivalence ratios and a trial to use the producer gas as a fuel of generator set. Only a few air-stage downdraft gasifiers have been reported so far. The present work is very essential work in order to develop a small-scale biomass power plant for remote areas in Indonesia.

\subsection{Novelty Statement}

A simple and low cost air-stage downdraft gasifier for a small-scale biomass power plant is designed and fabricated. No similar downdraft gasifier has been reported so far. The performance of the gasifier is evaluated on feedstock of rice husk waste at various equivalence ratios. Compared with 
other gasifiers, this gasifier generates producer gas with lower tar content without tar cleaning unit. The gravimetric tar of $23.9 \mathrm{mg} / \mathrm{m}^{3}$ is obtained at equivalence ratio of 0.4 . The producer gas is successfully used to run the $3 \mathrm{~kW}$ generator set. For sustainability operation of the power plant, it is recommended to test the gasifier on various biomass waste feedstocks.

\section{Methodology}

\subsection{Feedstock Characterization}

The feedstock of rice husk is collected from paddy milling industry in Bantul-Yogyakarta. The properties of proximate and ultimate of the husk are shown in Table 1 which is cited from work by Susastriawan et al., [40]. Those properties in the present work is assumed to be similar with previous one, since the feedstock of rice husk are collected from same site.

Table 1

The rice husk's proximate and ultimate properties [40]

\begin{tabular}{ll}
\hline Proximate property & Rice husk (wt\%, adb) \\
\hline FC (Fixed carbon) & 12.83 \\
VM (Volatile matter) & 56.20 \\
Ash & 21.17 \\
Moisture & 9.80 \\
Ultimate property & \\
Carbon & 34.05 \\
Hydrogen & 5.35 \\
Oxygen & 39.14 \\
Nitrogen & 0.17 \\
Sulphur & 0.12 \\
HHV (MJ/kg) & 13.39 \\
\hline
\end{tabular}

\subsection{Fabrication of the Gasifier}

The gasifier is fabricated from stainless steel. The inside and outside diameter of the gasifier are $200 \mathrm{~mm}$ and $300 \mathrm{~mm}$, respectively. The space between the two is filled with glass-wool insulator. The reactor has two air inlets, one near the grate and the other near the top of the reactor. Figure 1 shows the photographs of fabrication process and label of the gasifier part.
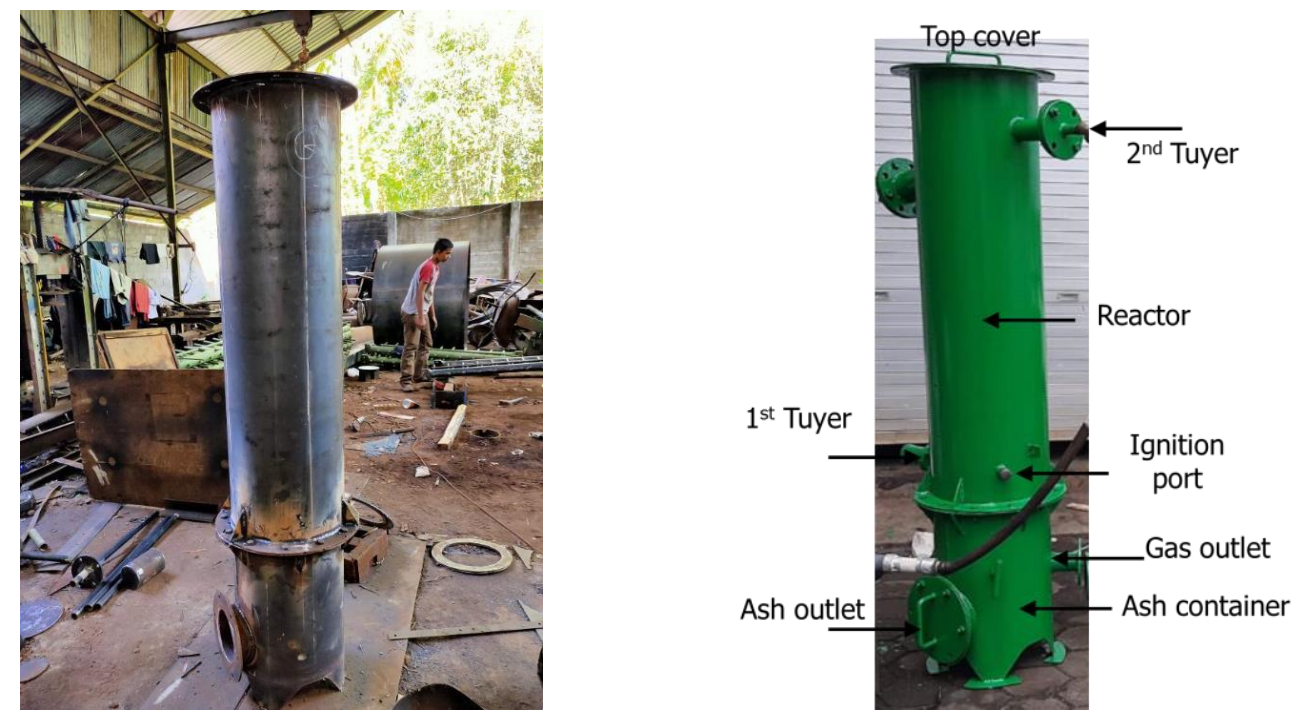

Fig. 1. Photograph of the fabrication process and parts of the gasifier 


\subsection{Experimental Work}

Figure 2 presents the schematic figure of the setup used in the present work. The system comprises an air-stage downdraft gasifier, air blower and fan, a flare, K-type thermocouples, rotameters, a level rod, impinging bottles, and a Water Boiling Test (WBT) unit. The WBT unit is basically pan containing some amount of water and a K-type thermocouple. The WBT aims to figure out heat transfer rate from a producer gas flame to the water in the pan and also to obtain thermal efficiency of the gasifier. The gasifier is run on a feedstock of rice husk in batch mode. The feedstock is filled into the gasifier from upper part of the reactor. Atmospheric air is supplied into the gasifier using blower through the primary and secondary tuyer. Gasification is initiated by igniting the feedstock through ignition port. A producer gas leaves the gasifier at outlet port located at a lower part of the reactor. The flare is used to burn the producer gas and its flame is used to boil the water in the WBT unit.

Volumetric air flow rate required is measured and maintained using rotameter. Axial temperatures of the gasifier are recorded using K-Type Thermocouples and the data is saved in Data Logger "Graphtec GL240". Tar in the producer gas is collected using the impinging bottles filled with an Isopropanol. Tar in the producer gas condenses and dissolves in Isopropanol. To obtain tar gravimetric, the isopropanol is heated at $50^{\circ} \mathrm{C}$ for 2 hours in an electric oven. The isopropanol evaporates and the remaining is a tar. This tar is weighting to calculate tar gravimetric.

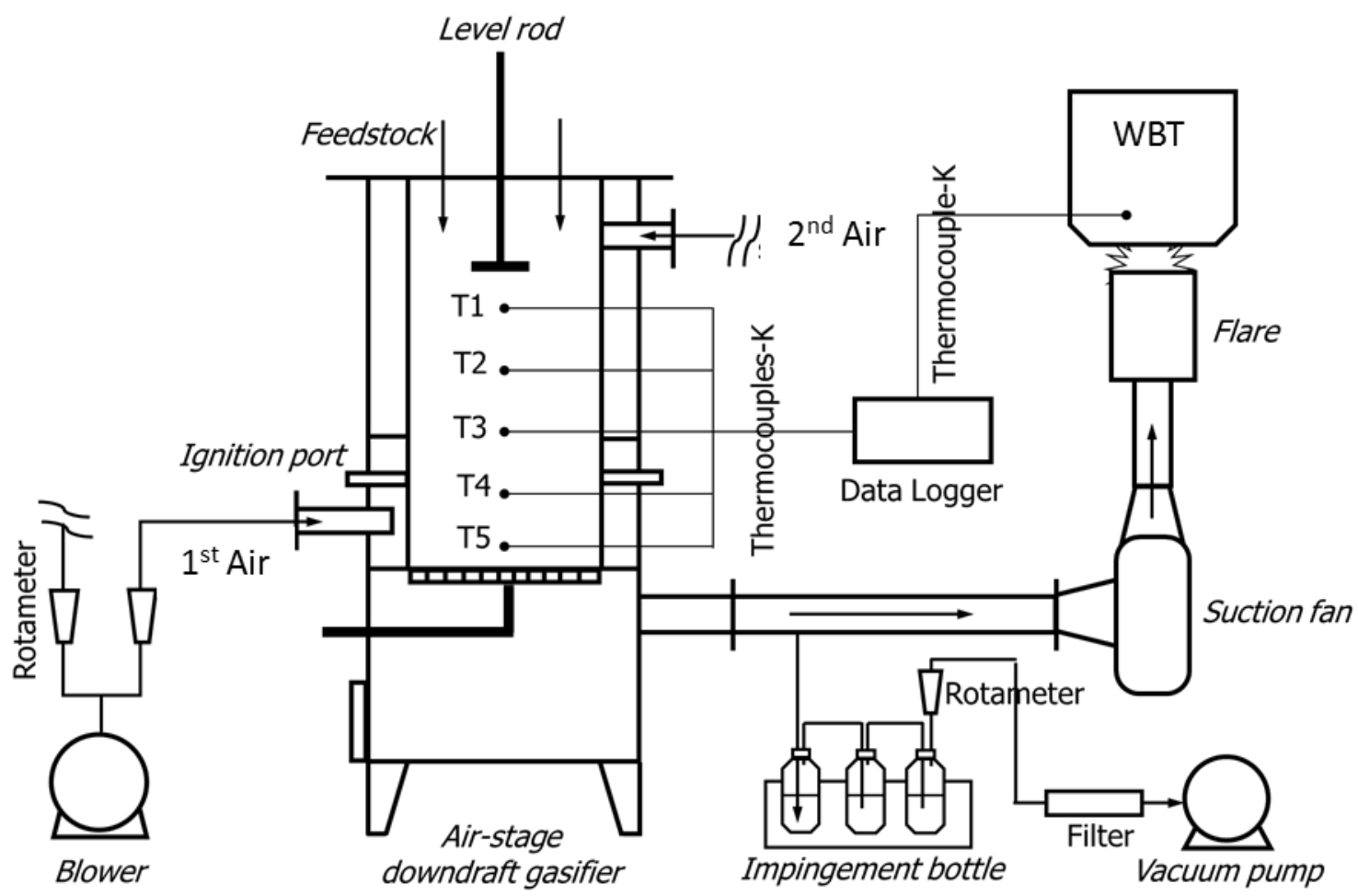

Fig. 2. Schematic diagram of an experimental setup

\subsection{Analysis of the Performance}

In the present work, the equivalence ratio investigated are $0.20,0.30$, and 0.40 . Axial temperatures of the gasifier are analysed at 50, 200,350, and $500 \mathrm{~mm}$ above the grate. Fuel consumption rate, heating rate to the WBT and thermal efficiency of the system are calculated using 
Eq. (1) to Eq. (3), respectively. Since during the test, mass of water vapour is very small, thus only sensible heat rate is accounted in the Eq. (2)

$F C R=\frac{\frac{\pi}{4} \times D^{2} \times(-\Delta h)}{\Delta t}$

$\dot{Q}=\frac{m_{w} \times c_{p} \times\left(T_{f}-T_{i}\right)}{t}$

$\eta=\frac{\dot{Q}}{m_{f} \times H H V_{f}} \times 100 \%$

where $D$ is the inside diameter of the gasifier $(200 \mathrm{~mm}), \Delta \mathrm{h}$ is the level rod movement $(\mathrm{mm}), \rho_{\mathrm{f}}$ is the density of the rice husk $\left(110 \mathrm{~kg} / \mathrm{m}^{3}\right), \Delta \mathrm{t}$ is the interval time of measuring downward movement of level rod (s), $m_{w}$ is the amount of water in WBT unit $(\mathrm{kg}), c_{p}$ is the water specific heat $(4186 \mathrm{~J} / \mathrm{kg} . \mathrm{K})$, $T_{f}$ and $T_{i}$ are the final and initial water temperatures $\left({ }^{\circ} \mathrm{C}\right)$ in the WBT, and $t$ is the test duration (s). Whereas, $\mathrm{m}_{\mathrm{f}}$ is the amount of the rice husk used $(\mathrm{kg})$ and $\mathrm{HHV}_{\mathrm{f}}$ is the rice husk's gross calorific value (13.39 MJ/kg).

\subsection{Application of the Producer Gas as a Fuel of Generator Set}

In this stage, the producer gas from rice husk gasification at equivalence ratio of 0.4 is used for fuelling a $3 \mathrm{~kW}$ generator set. The generator set used for the trial is bi-fuel generator set, i.e. either gasoline or liquid petroleum gas (LPG). The specification of the generator set is given in Table 2 . The gasifier-generator set system is shown in Figure 3. In order to cool the producer gas and to minimize tar content, the water spray scrubber is installed before the generator set. The test is performed by varying electrical load of the generator. The temperatures of the engine's cylinder block and exhaust gas temperature are measured using K-type thermocouples to figure out the engine condition during run on the producer gas. The rotation speed of the engine is measured using tachometer. Meanwhile, ampere and volt meter are used to measure electric current and voltage at generator output. Power output and torque of the generator are calculated using Eq. (4) and Eq. (5), respectively.

$P=V \times I$

$T=\frac{60 \times P}{2 \times \pi \times N}$

Table 2

Specification of the generator set

\begin{tabular}{ll}
\hline Parameter & Specification \\
\hline Bi-Fuel & Gasoline; LPG \\
Engine type & 4-stroke, single cylinder \\
Ignition system & Coil ignition \\
Cooling system & Air cooling \\
Generator AC output & $3 \mathrm{~kW}$ (Gasoline); 2 kW (LPG) \\
\hline
\end{tabular}




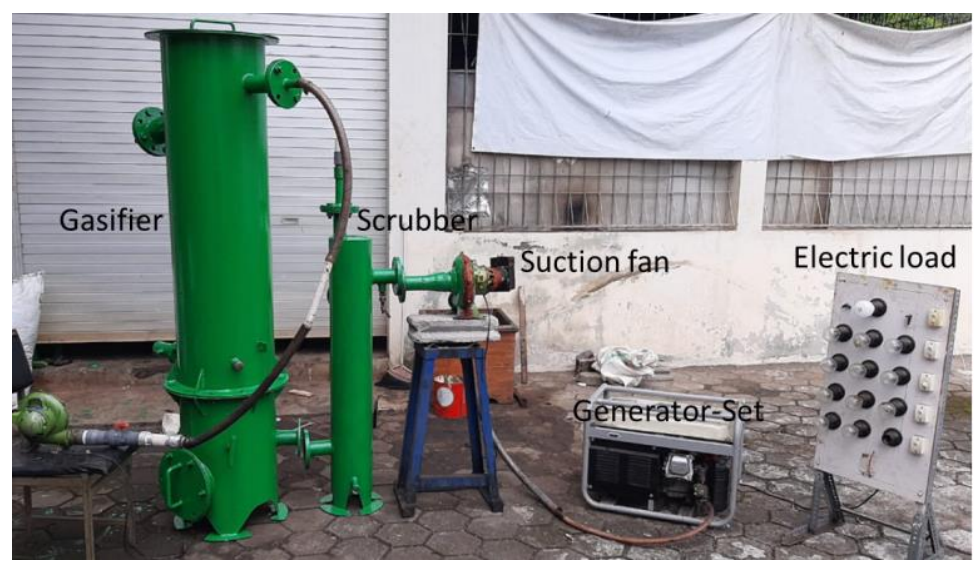

Fig. 3. Gasifier-generator set

\section{Results}

\subsection{Axial Temperature of the Gasifier}

Figure 4 displays an axial temperature profile of the gasifier after 5,15 , and 25 minute gasification time. It can be observed that the axial temperatures of the gasifier increase as gasification proceeds. More rice husk burnt as gasification proceeds and releasing more heat. The temperatures also improve as equivalence ratio steps up. More oxygen contents in air at higher equivalence ratio leads to enhance combustion of the rice husk. Enhancing combustion results in increasing heat released, thus temperature of the gasifier rises up. The trend of axial temperature profiles almost similar for equivalence ratio of $0.2,0.3$, and 0.4 . The axial temperature profiles indicate that the gasification zone lies between the grate and $200 \mathrm{~mm}$ above the grate. The maximum temperatures for each equivalence ratio occur at location of $200 \mathrm{~mm}$ above the grate.
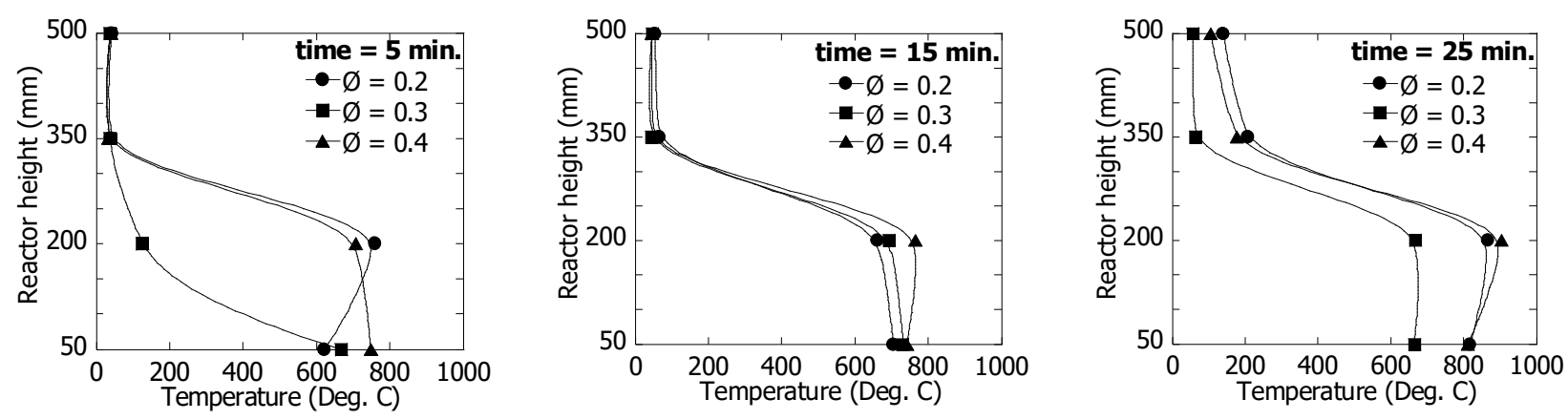

Fig. 4. Axial temperature profiles of the gasifier

\subsection{Feedstock Consumption Rate}

Feedstock consumption rate (FCR) within 25 minute of rice husk gasification at equivalence ratio of $0.2,0.3$, and 0.4 is shown in Figure 5. In general, the FCR increases rapidly within 10 minute gasification and reduces after 20 minutes at all equivalence ratios. Gasification at equivalence ratio of 0.4 consumes more rice husk than that at equivalence ratio of 0.2 and 0.3 . Oxidation rate is higher at equivalence ratio of 0.4 , thus more rice husk is gasified. Maximum FCR at equivalence ratio of 0.4 is $4.14 \mathrm{~kg} / \mathrm{h}$. After some extend, the FCR reduces. This is because fresh feedstock in the gasification zone has been gasified and the gasified feedstock obstructs the downward movement of the above fresh feedstock to the gasification zone which leads to slowdown the flame propagation and reduce fuel consumption rate. Exceptional at equivalence ratio of 0.2 , trend of the FCR is different. The FCR 
rises again after declining. This may due to the occurrence of bridging and channelling of the feedstock in the gasifier during gasification at equivalence ratio of 0.2 .

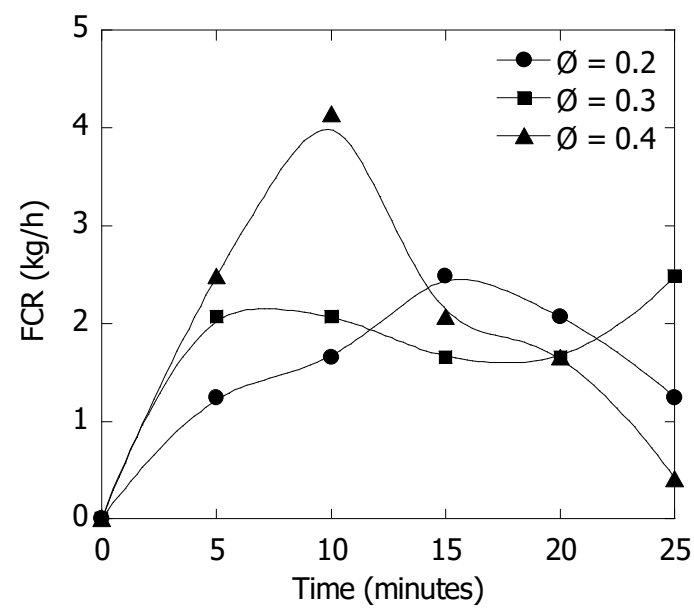

Fig. 5. Fuel consumption rate

\subsection{Heating Rate and Thermal Efficiency}

Heating rate is defined as the sensible energy of the flame to the water in the WBT unit. The heat from the producer gas flame is used to increase water temperature. Whereas, thermal efficiency is defined as the ratio between heating rate and energy content in the feedstock. Figure 6 presents heating rate and thermal efficiency for equivalence ratio of $0.2,0.3$, and 0.4 . Heating rate increases as increasing equivalence ratio. Better combustion occurs, since more oxygen is available for complete combustion at higher equivalence ratio. More heat is released by combustion during oxidation process at higher equivalence ratio, thus enhances the formation of $\mathrm{CO}, \mathrm{H}_{2}$, and $\mathrm{CH}_{4}$. Higher the composition of combustible gas, higher the energy content in the producer gas. Combustion of higher energy content producer gas results in higher flame temperature. Higher the temperature of the flame at higher equivalence ratio, higher the heating rate to the water in WBT unit as can be seen in Figure 6. Since thermal efficiency depends on heating rate, thus both thermal efficiency and heating rate have similar trend. Thermal efficiency improves as increasing equivalence ratio.

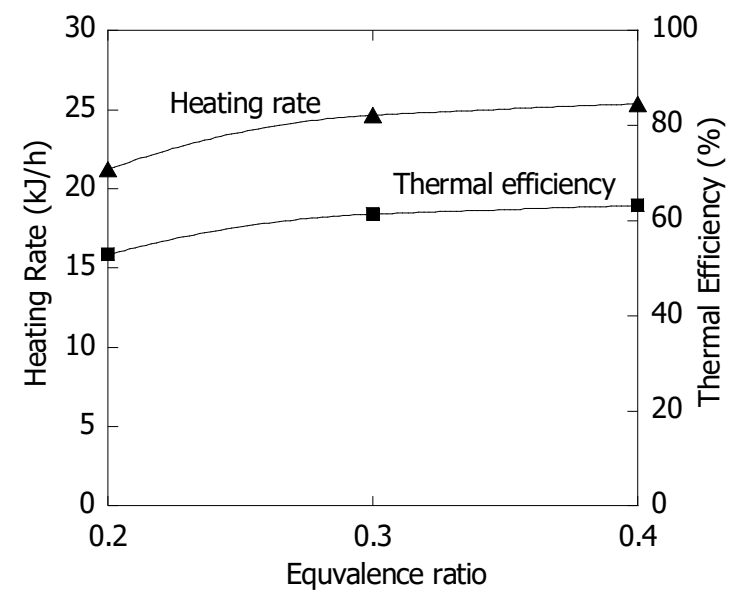

Fig. 6. Heating rate and thermal efficiency 


\subsection{Tar Content}

Tar contents in the producer gas is given in Figure 7. Tar content reduces as increasing equivalence ratio. Temperature of gasification zone is higher at higher equivalence ratio. This is due to enhancing heat released by oxidation. It can be stated that tar content minimizes by increasing gasification temperature. At higher temperature, some amount of tar crack to form condensable and combustible gas, thus generate low tar producer gas. The minimum tar contents of $23.97 \mathrm{mg}$ is observed at equivalence ratio of 0.4. Since maximum tar allowed for IC engine is $100 \mathrm{mg} / \mathrm{m}^{3}$ [38], thus the producer gas should be able to be used as a fuel of IC engine.

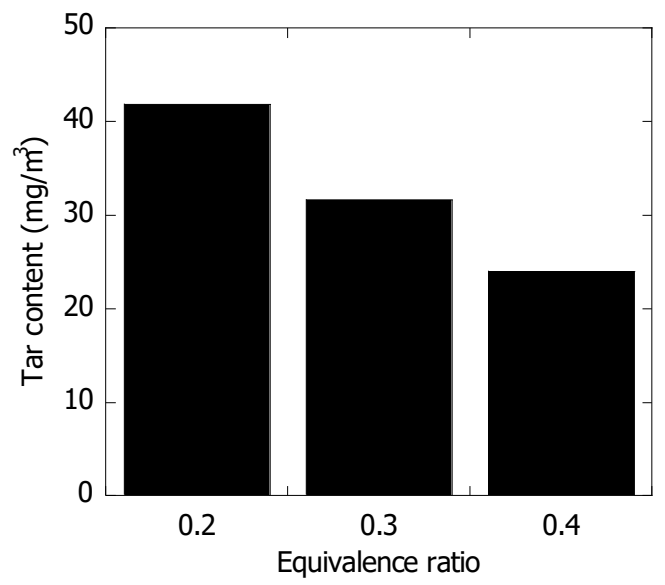

Fig. 7. Tar content

\subsection{Performance of a $3 \mathrm{~kW}$ Generator Set Fueled with the Producer Gas}

Producer gas from rice husk gasification at equivalence ratio of 0.4 is applied for fuelling a $3 \mathrm{~kW}$ generator set. The performance of the generator set in terms of engine rotational speed, torque, and power output is evaluated at electric load of 180,360,540, 720, 900, and $1080 \mathrm{~W}$. Figure 8 shows rotational speed of the engine at various electrical loads. The rotational speed of the engine decreases slightly as electric load increases, about $2500 \mathrm{rpm}$ at load of $180 \mathrm{~W}$ and about $1500 \mathrm{rpm}$ at load $1080 \mathrm{~W}$.

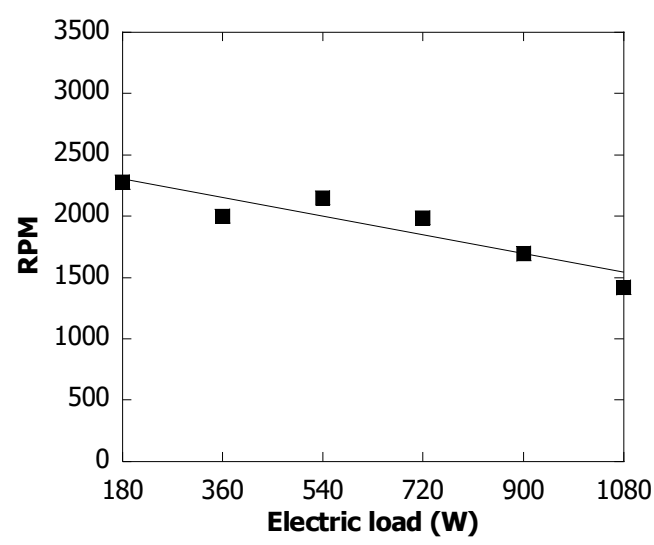

Fig. 8. Rotational speed of the engine 
The reduction in engine speed is due to the flow rate of the producer gas to the engine relatively constant for various electric loads during the test. The engine does not have a control device for regulating flow rate of the producer gas to the engine as per requirement according to the load. To maintain the engine speed at various loads, the generator set should be equipped with governor to control the flow rate of the producer gas to the engine automatically.

Meanwhile, Figure 9 presents power output of the generator and torque of the engine. The power output of the engine increases as increasing the load. Power generated by the engine is capable to supply enough power to the generator. Thus, the engine keep running even though the load of the generator increases. This means that the combustion of the producer gas in the cylinder can produce enough energy to develop power of the engine. Since the torque is a function of power output, the trend of the torque is similar with the power output, i.e. the torque steps up as increasing electrical load.

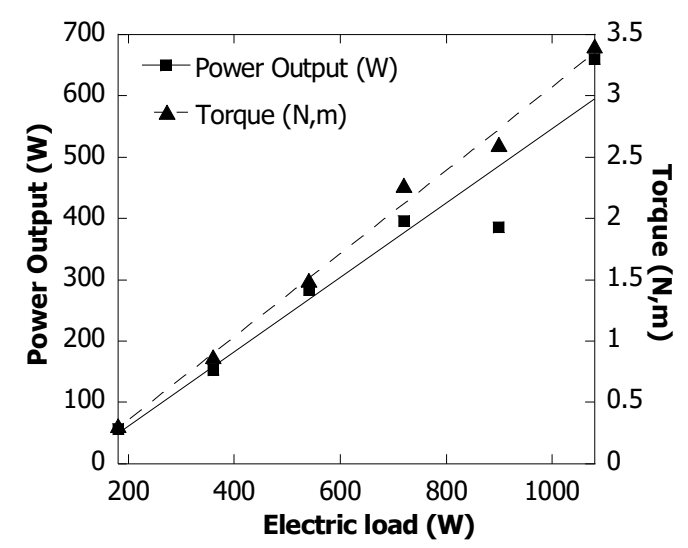

Fig. 9. Torque and power output

To figure out whether the engine experiences over heat or not, temperature of outside cylinder block and exhaust gas emission are observed during the trial. The temperature of the outer surface of the cylinder block and the temperature of exhaust gas emission are shown in Figure 10. The graph indicates that the engine run well without over heating for about 1 hour when the engine is fuelled with producer gas from rice husk gasification. From 10 minutes till 60 minutes, the temperatures of the cylinder and the exhaust gas increases insignificantly, relatively the temperatures are constant. This can be stated that the producer gas is suitable for the fuel of the $3 \mathrm{~kW}$ bi-fuel generator set since the engine did not experience any problems, including free from over heat.

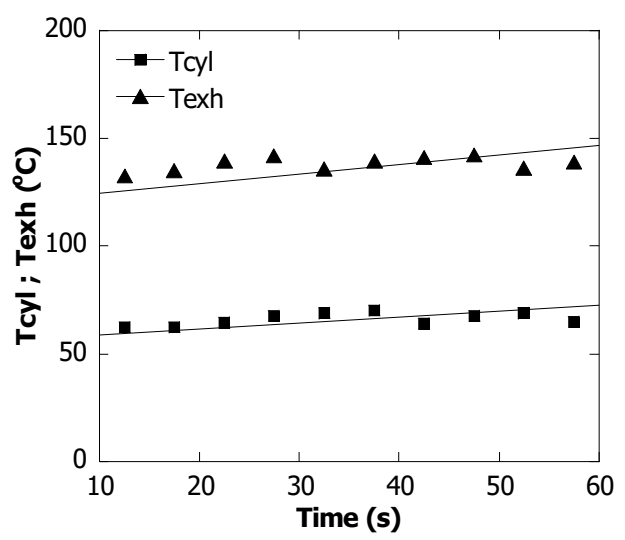

Fig. 10. Temperature of cylinder's block and exhaust gas 


\section{Conclusions}

The simple and low cost air-stage downdraft gasifier is designed, fabricated, and tested its performance on feedstock of rice husk at equivalence ratio of $0.2,0.3$, and 0.4 . It can be concluded that the performance of the gasifier is affected by equivalence ratio. Axial temperature, feedstock consumption rate, heating rate, and also thermal efficiency are higher at higher equivalence ratio. Meanwhile, tar content is lower at higher equivalence ratio. The highest temperature, feedstock consumption rate, heating rate, and thermal efficiency occur at equivalence ratio of 0.4 . The values are $904.5^{\circ} \mathrm{C}, 4.14 \mathrm{~kg} / \mathrm{h}, 25.38 \mathrm{~kJ} / \mathrm{h}$, and $63.18 \%$, respectively. Minimum tar content of $23.9 \mathrm{mg} / \mathrm{m}^{3}$ is observed at equivalence ratio of 0.4. The producer gas is successfully used to run the $3 \mathrm{~kW}$ generator set. The generator set operates well without over heating during the test. It can be stated that the gasifier is suitable to be coupled with the generator set to build a small-scale biomass power plant.

\section{Acknowledgement}

Thank comes to DRPM-RISTEK/BRIN-Republic of Indonesia for the financial support of the present work under the scheme of PDUPT 2021. The author also thanks to LPPM IST AKPRIND for the administrative assistance.

\section{References}

[1] Aslfattahi, Navid, R. Saidur, Nor Azwadi Che Sidik, Mohd Faizul Mohd Sabri, and Md Hasan Zahir. "Experimental assessment of a novel eutectic binary molten salt-based hexagonal boron nitride nanocomposite as a promising PCM with enhanced specific heat capacity." Journal of Advanced Research in Fluid Mechanics and Thermal Sciences 68, no. 1 (2020): 73-85. https://doi.org/10.37934/arfmts.68.1.7385

[2] Sikarwar, Vineet Singh, Ming Zhao, Paul S. Fennell, Nilay Shah, and Edward J. Anthony. "Progress in biofuel production from gasification." Progress in Energy and Combustion Science 61 (2017): 189-248. https://doi.org/10.1016/i.pecs.2017.04.001

[3] Bernocco, Daniele, Barbara Bosio, and Elisabetta Arato. "Feasibility study of a spouted bed gasification plant." Chemical engineering research and design 91, no. 5 (2013): 843-855. https://doi.org/10.1016/j.cherd.2012.09.012

[4] Gujar, Amit C., Jong Baik, Nathaniel Garceau, Nazim Muradov, and T. Ali. "Oxygen-blown gasification of pine charcoal in a top-lit downdraft moving-hearth gasifier." Fuel 118 (2014): 27-32. https://doi.org/10.1016/j.fuel.2013.10.039

[5] Perpres 22 Tahun 2017. "Peraturan Presiden Republik Indonesia Nomor 22 Tahun 2017 tentang Rencana Umum Energi Nasional." (2017).

[6] Erkiaga, Aitziber, Gartzen Lopez, Maider Amutio, Javier Bilbao, and Martin Olazar. "Influence of operating conditions on the steam gasification of biomass in a conical spouted bed reactor." Chemical engineering journal 237 (2014): 259-267. https://doi.org/10.1016/i.cej.2013.10.018

[7] Hernández, Juan J., Guadalupe Aranda-Almansa, and Antonio Bula. "Gasification of biomass wastes in an entrained flow gasifier: Effect of the particle size and the residence time." Fuel Processing Technology 91, no. 6 (2010): 681692. https://doi.org/10.1016/i.fuproc.2010.01.018

[8] Basu, Prabir. Biomass gasification and pyrolysis: practical design and theory. Academic press, 2010.

[9] Guangul, Fiseha M., Shaharin A. Sulaiman, and Anita Ramli. "Gasifier selection, design and gasification of oil palm fronds with preheated and unheated gasifying air." Bioresource technology 126 (2012): $224-232$. https://doi.org/10.1016/j.biortech.2012.09.018

[10] Vyarawalla, F., P. P. Parikh, H. C. Dak, and B. C. Jain. "Utilisation of biomass for motive power generation-gasifier engine system." Biomass 5, no. 3 (1984): 227-242. https://doi.org/10.1016/0144-4565(84)90024-6

[11] Indrawan, Natarianto, Sunil Thapa, Prakashbhai R. Bhoi, Raymond L. Huhnke, and Ajay Kumar. "Engine power generation and emission performance of syngas generated from low-density biomass." Energy Conversion and Management 148 (2017): 593-603. https://doi.org/10.1016/i.enconman.2017.05.066

[12] Nadaleti, Willian Cézar, and Grzegorz Przybyla. "SI engine assessment using biogas, natural gas and syngas with different content of hydrogen for application in Brazilian rice industries: Efficiency and pollutant 
emissions." International Journal of Hydrogen Energy 43, no. $21 \quad$ (2018): 10141-10154. https://doi.org/10.1016/i.ijhydene.2018.04.073

[13] Tsiakmakis, Stefanos, Dimitrios Mertzis, Athanasios Dimaratos, Zisimos Toumasatos, and Zissis Samaras. "Experimental study of combustion in a spark ignition engine operating with producer gas from various biomass feedstocks." Fuel 122 (2014): 126-139. https://doi.org/10.1016/j.fuel.2014.01.013

[14] Singh, Harmanpreet, and S. K. Mohapatra. "Production of producer gas from sugarcane bagasse and carpentry waste and its sustainable use in a dual fuel $\mathrm{Cl}$ engine: A performance, emission, and noise investigation." Journal of the Energy Institute 91, no. 1 (2018): 43-54. https://doi.org/10.1016/i.joei.2016.11.002

[15] Ramadhas, A. S., S. Jayaraj, and C. Muraleedharan. "Dual fuel mode operation in diesel engines using renewable fuels: Rubber seed oil and coir-pith producer gas." Renewable Energy 33, no. 9 (2008): $2077-2083$. https://doi.org/10.1016/j.renene.2007.11.013

[16] Yaliwal, V. S., N. R. Banapurmath, R. S. Hosmath, S. V. Khandal, and Wojciech M. Budzianowski. "Utilization of hydrogen in low calorific value producer gas derived from municipal solid waste and biodiesel for diesel engine power generation application." Renewable $\quad$ Energy $99 \quad$ (2016): 1253-1261. https://doi.org/10.1016/i.renene.2016.08.002

[17] Ismail, Tamer M., and M. Abd El-Salam. "Parametric studies on biomass gasification process on updraft gasifier high temperature air gasification." Applied Thermal Engineering $112 \quad$ (2017): 1460-1473. https://doi.org/10.1016/j.applthermaleng.2016.10.026

[18] Reed, Thomas B., and Agua Das. Handbook of biomass downdraft gasifier engine systems. Biomass Energy Foundation, 1988. https://doi.org/10.2172/5206099

[19] Kaupp, A., and J. R. Goss. State-of-the-art report for small scale (to $50 \mathrm{kw}$ ) gas producer-engine systems. No. PB-85102002/XAD. California Univ., Davis (USA). Dept. of Agricultural Engineering, 1981.

[20] Olgun, Hayati, Sibel Ozdogan, and Guzide Yinesor. "Results with a bench scale downdraft biomass gasifier for agricultural and forestry residues." Biomass and bioenergy 35, no. 1 (2011): 572-580. https://doi.org/10.1016/j.biombioe.2010.10.028

[21] Guo, Feiqiang, Yuping Dong, Lei Dong, and Chenlong Guo. "Effect of design and operating parameters on the gasification process of biomass in a downdraft fixed bed: An experimental study." International journal of hydrogen energy 39, no. 11 (2014): 5625-5633. https://doi.org/10.1016/i.ijhydene.2014.01.130

[22] Tinaut, Francisco V., Andrés Melgar, Juan F. Perez, and Alfonso Horrillo. "Effect of biomass particle size and air superficial velocity on the gasification process in a downdraft fixed bed gasifier. An experimental and modelling study." Fuel processing technology 89, no. 11 (2008): 1076-1089. https://doi.org/10.1016/j.fuproc.2008.04.010

[23] Chen, Wei, Kalyan Annamalai, R. James Ansley, and Mustafa Mirik. "Updraft fixed bed gasification of mesquite and juniper wood samples." Energy 41, no. 1 (2012): 454-461. https://doi.org/10.1016/j.energy.2012.02.052

[24] Gu, Haidong, Yuanzheng Tang, Jian Yao, and Feng Chen. "Study on biomass gasification under various operating conditions." Journal of the Energy Institute 92, no. 5 (2019): 1329-1336. https://doi.org/10.1016/i.joei.2018.10.002

[25] Yuan, Wenqiao, Michael D. Boyette, and Donghai Wang. "Airflow and insulation effects on simultaneous syngas and biochar production in a top-lit updraft biomass gasifier." Renewable Energy 117 (2018): 116-124. https://doi.org/10.1016/j.renene.2017.10.034

[26] Aljbour, Salah H., and Katsuya Kawamoto. "Bench-scale gasification of cedar wood-Part I: Effect of operational conditions on product gas characteristics." Chemosphere 90, no. $4 \quad$ (2013): $1495-1500$. https://doi.org/10.1016/j.chemosphere.2012.08.029

[27] Wang, Zhiqi, Tao He, Jianguang Qin, Jingli Wu, Jianqing Li, Zhongyue Zi, Guangbo Liu, Jinhu Wu, and Li Sun. "Gasification of biomass with oxygen-enriched air in a pilot scale two-stage gasifier." Fuel 150 (2015): 386-393. https://doi.org/10.1016/i.fuel.2015.02.056

[28] Liu, Huili, Jianhang Hu, Hua Wang, Chao Wang, and Juanqin Li. "Experimental studies of biomass gasification with air." Journal of natural gas chemistry 21, no. 4 (2012): 374-380. https://doi.org/10.1016/S1003-9953(11)60379-4

[29] Ayyadurai, Saravanakumar, Loek Schoenmakers, and Juan José Hernández. "Mass and energy analysis of a 60 kWth updraft gasifier using large size biomass." Fuel 187 (2017): 356-366. https://doi.org/10.1016/j.fuel.2016.09.080

[30] Ding, Lu, Kunio Yoshikawa, Minoru Fukuhara, Yuto Kowata, Shunsuke Nakamura, Dai Xin, and Li Muhan. "Development of an ultra-small biomass gasification and power generation system: Part 2. Gasification characteristics of carbonized pellets/briquettes in a pilot-scale updraft fixed bed gasifier." Fuel 220 (2018): 210219. https://doi.org/10.1016/i.fuel.2018.01.080

[31] Kardaś, Dariusz, Jacek Kluska, and Paweł Kazimierski. "The course and effects of syngas production from beechwood and RDF in updraft reactor in the light of experimental tests and numerical calculations." Thermal Science and Engineering Progress 8 (2018): 136-144. https://doi.org/10.1016/i.tsep.2018.08.020 
[32] Tian, Tian, Qinghai Li, Rong He, Zhongchao Tan, and Yanguo Zhang. "Effects of biochemical composition on hydrogen production by biomass gasification." International Journal of Hydrogen Energy 42, no. 31 (2017): 1972319732. https://doi.org/10.1016/j.ijhydene.2017.06.174

[33] Anis, Samsudin, and Z. A. Zainal. "Tar reduction in biomass producer gas via mechanical, catalytic and thermal methods: A review." Renewable and sustainable energy reviews 15, no. 5 (2011): 2355-2377. https://doi.org/10.1016/i.rser.2011.02.018

[34] Woolcock, Patrick J., and Robert C. Brown. "A review of cleaning technologies for biomass-derived syngas." Biomass and bioenergy 52 (2013): 54-84. https://doi.org/10.1016/i.biombioe.2013.02.036

[35] Rios, Martha Lucia Valderrama, Aldemar Martínez González, Electo Eduardo Silva Lora, and Oscar Agustin Almazán del Olmo. "Reduction of tar generated during biomass gasification: A review." Biomass and bioenergy 108 (2018): 345-370. https://doi.org/10.1016/i.biombioe.2017.12.002

[36] Pallozzi, V., A. Di Carlo, E. Bocci, and M. Carlini. "Combined gas conditioning and cleaning for reduction of tars in biomass gasification." Biomass and Bioenergy 109 (2018): 85-90. https://doi.org/10.1016/i.biombioe.2017.12.023

[37] Zhai, Ming, Xinyu Wang, Yu Zhang, Peng Dong, Guoli Qi, and Yudong Huang. "Characteristics of rice husk tar secondary thermal cracking." Energy 93 (2015): 1321-1327. https://doi.org/10.1016/i.energy.2015.10.029

[38] Milne, Thomas A., Robert J. Evans, and N. Abatzaglou. "Biomass gasifier"'Tars": their nature, formation, and conversion." (1998). https://doi.org/10.2172/3726

[39] Zendehboudi, Alireza, Navid Aslfattahi, Saidur Rahman, Mohd Faizul Mohd Sabri, Suhana Mohd Said, A. Arifutzzaman, and Nor Azwadi Che Sidik. "Optimization of Thermal Conductivity of NanoPCM-Based Graphene by Response Surface Methodology." Journal of Advanced Research in Fluid Mechanics and Thermal Sciences 75, no. 3 (2020): 108-125. https://doi.org/10.37934/arfmts.75.3.108125

[40] Susastriawan, A. A. P., and Harwin Saptoadi. "Effect of tuyer distance above grate on propagation front and performance of downdraft gasifier with the feedstock of rice husk." Renewable Energy 134 (2019): 1034-1041. https://doi.org/10.1016/i.renene.2018.11.110 